M. E. SALTYKOV-SHCHEDRIN: SELECTED SATIRICAL WRITINGS. Edited by I. P. Foote. Oxford: Clarendon Press, 1977. vi, 284 pp. $\$ 21.00$.

The Russian texts in this volume are reprints from the recent collected edition of M. E. Saltykov-Shchedrin's works (Sobranie sochinenii [Moscow, 1965-76]). Four unabridged fairy tales and thirty-one extracts from Saltykov's major works are grouped according to a rough thematic scheme: numbers $1-8$ deal with relations between the Russian state and the people; numbers 9-15 with the emancipation, reform, and counterreform; numbers 16-21 with aspects of the postreform period and social changes; numbers $22-25$ with the liberals; number 26 with the zemstvo; numbers 27-32 with the political mood of Russia in the late 1870s and the 1880s; and numbers 33-35 with Saltykov's literary position and satirical method. The selected passages are more or less self-contained and illustrate Saltykov's attitude toward the major problems of his day, as well as the range of his technique as a satirist as found in the following works: Gubernskie ocherki (1856-57), Satiry v proze (1859-62), Pompadury i pompadurshi (1863-74), Istoriia odnogo goroda (1869-70), Skazki (1869-86), Gospoda tashkenttsy (1869-72), Dnevnik provintsiala v Peterburge (1872), Blagonamerennye rechi (1872-76), $V$ srede umerennosti $i$ akkuratnosti (1876), Sovremennaia idiliia (1877-83), Ubezhishche Monrepo (1878-79), Kruglyi god (1879-80), Za rubezhom (1881), Pis'ma k teten'ke (1881-82), Melochi zhizni (1886-87).

The collection includes a substantial introduction by Foote, introductory notes to the individual items, commentaries to all the texts, a glossary of rare words, and a select bibliography, all of which provide reliable information on Saltykov's life and work as well as on the historical background of mid-nineteenth-century Russia. Foote's contribution is scholarly, though he is indebted to the commentaries contained in the Sobranie sochinenii. According to Foote, Saltykov is "too literary for the historian and too historical for the student of literature, and he has been largely ignored by both" (p. 1). He points out that the aim of the present volume is to correct this situation, which, I should add, prevails only outside of Saltykov's native country. The "merciless satirist" of the old regime is one of the "most-printed" and "most-studied" writers in the Soviet Union (see Maurice Friedberg, Russian Classics in Soviet Jackets [New York, 1962], p. 33).

This "Portable Saltykov" can be read with pleasure by lovers of humor and satire, and should also provide a useful service in courses on Russian culture and civilization, because the selected passages offer a vivid insight into some of the main political and social problems of Saltykov's day. The lack of detailed linguistic commentary to the texts is regrettable, however, because it precludes their use in advanced Russian language courses.

A serious student of literature normally prefers to read and analyze the complete text of an entire work of art rather than extracts. Consequently, Selected Satirical Writings has little or no appeal to specialists, although the collection may be useful as a review source for Saltykov's satires.

Catherine Kulesov

University of Minnesota

\title{
D. S. MEREŽKOVSKIJ ALS LITERATURKRITIKER: VERSUCH EINER RELIGIÖSEN BEGRUNDUNG DER KUNST. By Ute Spengler. Slavica Helvetica, vol. 2. Lucerne: C. J. Bucher, 1972. 174 pp.
}

Of the entire corpus of Merezhkovskii's work, his literary criticism has best stood the test of time. "On the Causes of the Decline of Russian Literature" is frequently considered the manifesto of Russian Symbolism; "Gogol and the Devil" was included 
in Robert A. Maguire's recent anthology of Gogol criticism, and, according to Victor Erlich, the "insights and inages" of Tolstoy and Dostoevsky "have reverberated well into recent Western criticism." Lesser-known critical works, such as Vechnye sputniki (parts of which have been published in English), are interesting for the insights they offer on the greats of world literature. Thus a study of Merezhkovskii as a literary critic can add a vital dimension to our understanding of him and of his place in Russian history and culture.

Ute Spengler's study of Merezhkovskii traces the development of the religious foundation of his work, concluding that his literary criticism was the fulfillment of his religious philosophy. She argues her thesis persuasively, showing that his literary activity was motivated by his search for a unifying philosophy of life, and demonstrating how his concerns with existential questions-the meaning of life, the reason for suffering, and the nature of freedom-evolved into an explicitly religious world view. Her treatment of topics such as Thomas Carlyle's influence on Merezhkovskii (Jesus as the prototype of the hero), Merezhkovskii's verse-drama "Sylvio," and his reception by literary critics adds to our knowledge of the man and his times. Spengler also draws interesting parallels between Merezhkovskii's search for unity and the Lebensphilosophie of the German writer Wilhelm Dilthey, who, similarly disillusioned with positivism, rationalism, and bourgeois values, and similarly occupied with the problems of newly self-conscious modern man, sought "transcendence," she claims, in myth rather than in Logos. Her discussion of influences on Merezhkovskii, however, fails to mention the influence of Vissarion Belinskii, on whom Merezhkovskii modeled himselfMerezhkovskii hoped to use literary criticism to change the consciousness of his contemporaries, just as Belinskii did.

Although Merezhkovskii attacked the didactic tradition of Russian literature associated with Belinskii, he was never, as Spengler points out, a believer in art for art's sake. Calling for the development of a literary language capable of expressing great ideas and emphasizing art and beauty as values, he always insisted on the unity of form and content. Unfortunately, Spengler's study includes no analysis of Merezhkovskii's form (the way he used the language, the tone and texture of his prose, alliteration, repetition, sound patterns, plays on words, choice of words, use of quotations), aspects that could cast new light on his perception of the world, his religious sensibility, the message he wished to communicate (and actually did communicate) in his literary criticism, and his influence on Russian Symbolism. To omit these "formal" aspects of his work is to omit a vital dimension of Merezhkovskii as a literary critic.

\section{Bernice Glatzer Rosenthal Fordham University}

\section{BULAT OKUDŽAVA UND DIE KRITISCHE LITERATUR UBER DEN} KRIEG. By Karl-Dieter van Ackern. Arbeiten und Texte zur Slavistik, 11. Munich: Verlag Otto Sagner in Kommission, 1976. 196 pp. DM 20, paper.

The theme of war occupies an important place in contemporary Soviet literature. Most works depicting the Second World War are written in the spirit of partiinost' and emphasize the dedication of Soviet man to the objectives of the party. In the postStalin era, however, there has been an evolution in the treatment of war in literature: the glorification of the Soviet war effort is often replaced by a more realistic portrayal of the fears and anguish of solitary man in the face of mortal danger. A number of writers, including G. Baklanov, V. Bykov, and B. Okudzhava, began to describe the war in unheroic terms and to expose its brutality and its devastating effect on man.

The book under review is a doctoral dissertation accepted at the University of Cologne. The author analyzes the creative activity of Bulat Okudzhava, particularly 